\title{
The Impacts of Basel III on the Global Banking Regulations and the Responses of Regulatory Systems
}

\author{
Xiaotong He
}

\author{
School of Law, University of Sydney, Australia \\ *Corresponding author.Email: hexit0903@163.com
}

\begin{abstract}
In 2007 and 2008, a wave of financial crises swept across the globe. The crisis exposed the low liquidity of capital and the inadequacy of the regulatory system under the Basel II. In order to ensure the stability of the international financial environment, the Basel Committee on Banking Supervision published the latest revision of Basel III in 2010. This essay examines the impact of the newly introduced Basel III on countries around the world, what countries around the world have done in response, as well as analyzing the shortcomings of China's current policies. In addition, to make recommendations based on the experience of other countries with regard to the problems that exist in our country and establish a Chinese regulatory system which is connecting with the world.
\end{abstract}

Keywords: Basel III, banking industry, regulation, impacts

\section{INTRODUCTION}

\subsection{The background of Basel III}

The financial crisis that swept the world between 2007 and 2008 [1], which caused capital depletion [2] and led to the precariousness and even the failure of many banks [3]. In the face of the financial crisis, the Basel Committee on Banking Supervision and experts from the world have found some shortcomings in the international financial regulatory system under the Basel II framework [4]. In order to prevent more banking industry failures, to keep the global economy stable, to avoid another financial crisis, and to strengthen the international banking system [4], Basel Committee on Banking Supervision upgrades and builds on Basel II, then Basel III was published [1].

\subsection{The key contents of Basel III}

\subsubsection{Increase in minimum capital requirements}

In Basel II, capital was divided into three tiers: Tier 1, Tier 2 and Tier 3 [5]. The minimum ratio of risk-weighted assets in the form of common equity is 2 $\%$ and the minimum Tier 1 capital is $4 \%$ [1]. However, after the financial crisis, the two percent risk-weighted asset common equity holdings were so low that there was an under-capitalization and low quality of global banks, which led to losses and even failures of many banks [5]. As a result, the previous Tier 3 capital was eliminated in the newly released Basel III, and increased the minimum common equity Tier 1 capital ratio to 4.5 $\%$ and the minimum capital to $6 \%$ [5]. At the same time, the concepts of capital conservation buffer and counter-cyclical buffer were introduced to protect the banking system and reduce stress [1].

\subsubsection{Introduction of the concept of leverage ratio}

As a result of the financial crisis, the asset value of the banking industry has shrunk significantly [1]. The Basel Committee on Banking Supervision introduced the concept of the leverage ratio in order to control the banking industry's risk exposure, regulate capital arbitrage and restore the overall strength of the banking industry [5]. A minimum bank leverage ratio of $3 \%$ is set in Basel III [6].

\subsubsection{Introduction of liquidity coverage and net stable funding ratios}

In contrast to the static regulatory instruments of the previous two versions of Basel, Basel III introduces the concepts of liquidity coverage ratio and net stable funding ratio for liquidity regulation [6]. In order to have sufficient and high quality funding to avoid 
short-term liquidity shocks, banks are encouraged to restructure their funding [2], with both ratios exceeding $100 \%$.

\subsubsection{Revised content for 2017}

Basel III in 2017 was revised primarily to reduce the degree of variability in risk-weighted assets to prevent excessive variability [7]. There are two ways to reduce it and restoring confidence in risk-weighted assets ratios. On the one hand, in order to enhance the the comparability of bank capital ratios, the new version of Basel III restricts the use of internal modeling methods and requires that the minimum risk measure be no less than $72.5 \%$ of the standard method measure [8]. On the other hand, while the leverage ratio requirement for commercial banks in the new version remains at $3 \%$ as set out in the 2010 version, the new version has higher leverage requirements for global systemically important banks (G-SIBs) [7]. The G-SIB minimum leverage ratio is equal to the sum of the minimum leverage ratio for ordinary commercial banks and $50 \%$ of the additional capital requirement for G-SIBs [9].

\section{REFORM OF FINANCIAL REGULATORY SYSTEMS AROUND THE WORLD UNDER THE BASEL III FRAMEWORK}

Following the publication of Basel III, the Bank for International Settlements (BIS) calculated that more than 90 percent of the 28 participating states had reacted promptly to the publication of the new Basel III [2]. Additionally, a quarter of these states have issued final rules for Basel III [2]. The publication of Basel III will create a resilient global banking system and reduce the risk of bank failures by controlling the quality of capital [4]. However, some experts believe that an overly stringent Basel III will not only not reduce the risk of bank failures, but its excessive capital standards will lead to a slowdown in currency flows and burden the banking sector [1].

\subsection{U.S. makes regulatory changes in response to Basel III}

At the beginning, the sub-prime mortgage crisis spread globally with the United States at its center, the newly revised Basel is more specific to the problems of the U.S. banking sector [10]. In order to restore the country's economy, improve its regulatory system and make a response to Basel, the U.S. House of Representatives passed the Dodd-Frank Wall Street Reform and Consumer Protection Act [10]. The act is important in reforming the regulatory system and maintaining financial stability [11].

\subsubsection{Strengthened risk-based regulatory standards}

The main ways to strengthen risk regulation is through methods such as increasing capital adequacy and leverage ratios [10]. The minimum capital adequacy ratio for the banking sector under the Basel is eight percent. In addition, United States global systemically important banks have increased their risk-weighted assets ratios by a certain amount. JPMorgan Chase, for example, was required to raise its risk-weighted assets by $2.5 \%$ [10]. At the same time, in order to effectively improve the domestic financial environment of the United States to achieve economic recovery, the Federal Reserve approved the banks to implement the contents of the new Basel [10]. Both the minimum tier 1 capital and general leverage ratios increased.

\subsubsection{Expansion of the Federal Reserve System's (Fed) power}

In the U.S. regulatory reform package in response to Basel III, the Federal Reserve was given more powers such as control bank risk, and also to expand the scope of its supervision such as in the insurance sector [12]. However, the most important aspect of expanding the Fed's functions is that the Fed will also be responsible for regulating executive compensation in the banking industry [11]. This is to prevent and control executives from ignoring potential risks in pursuit of their own greater interests. The act also requires the Federal Reserve to comply with the principles of prudential supervision when supervising banks with assets exceeding $\$ 50$ billion [13]. While giving the Federal Reserve more functions, it also places restrictions on the Fed [11]. For example, the Fed must disclose the content of agreements with foreign central banks and be accountable to the government [10].

In conclusion, the US reform package is a major restructuring of its banking regulatory system, not only to further improve its national regulatory system but also to facilitate the implementation of Basel III.

\subsection{United Kingdom makes regulatory changes in response to Basel III}

Since the UK's regulatory system was more complete than other countries before the wave of financial crisis hit [12]. As the result, the financial crisis at that time did not bring great losses to the UK. Therefore, after the announcement of Basel III, there is no major change in the UK regulatory system, instead of the original system to repair and enhance the loopholes [11].

In order to stabilize the banking sector and address the issues revealed during the financial crisis, the UK enacted the Banking Act in 2009, mainly to establish the 
centrality and clarify the responsibilities of the Bank of England [11]. In addition, the Act establishes a special resolution regime and a Financial Stability Commit-tee (FSC) [12]. These two initiatives not only improve the specific corresponding compensation plan after financial services [12], but also can play a role in the early warning and identification of financial risks, greatly reducing the uncontrollable factors of financial risk [11]. It's worth mentioning that the concept of strengthening banking supervisory standards is explicitly set out in the white paper on reforming financial markets [10].

\subsection{European Union makes regulatory changes in response to Basel III}

The European banking industry has always had a close business relationship with the US banking industry, which led to the EU becoming the second union of countries to be severely affected by the financial crisis after the US was affected by the financial crisis [12]. Before the new version of Basel, the EU had implemented the Capital Requirements Directive (CRD) to regulate banking capital [5]. In order to complete the reform of capital in accordance with the Basel, the EU will adopt a regulatory approach. Besides, the implementation of the Capital Requirements Regulation (CRR) will be used as a complementary piece of legislation [5].

\subsubsection{Establishment of macro-management mechanisms}

The EU developed companion draft legislation in 2009, defining specific reforms, and also established an EU Systemic Risk Board (ESRB) [14]. Although the reform plan formulated by the $\mathrm{EU}$ and the implementation of the use of laws and regulations to replace CRD have caused dissatisfaction among EU member states, the method of reform can enable the application of the same rule--Basel III in the EU region, which is conducive to healthy competition within the banking industry [5]. The ESRB's function is to conduct prudential supervision, providing early warning of risks in the banking sector, assessing them and giving advice on how to mitigate them [12]. In general, the EU reform is based on the issuance of relevant legislative acts and the establishment of functional departments with macro-regulatory powers to achieve better regulation and reduce risk.

\subsubsection{Improving the legislative system}

Nowadays, the process of world integration is accelerating, and the EU is aware that only cooperation among countries in the field of cross-border financial regulation can truly improve the regulatory system [12]. Therefore, the EU has created a permanent regulator, the Joint Committee of Financial Conglomerates (JCFC)
[11]. The function of the committee is to supervise the implementation of financial regulatory policies in various countries [15]. The European Council also changed the original Insurance, Securities and Banking Regulatory Commission into the European Supervisory Authorities (ESA), which is responsible to the European Commission and the Council [11]. As a result, the European Commission, the European Commission, the Joint Commission of Financial Groups and the European Supervisory Authorities together constitute the EU's unique financial supervision system.

\section{CHINA'S BANKING REGULATION STATUS AND INSUFFICIENCY UNDER THE BASEL III FRAMEWORK}

\subsection{Current status}

In China, the current financial supervision system is relatively complete, consisting of a bank and two committees as an overall framework [16]. Among them, one bank refers to the People's Bank of China and its subsidiaries, and the two committees refer to the China Securities Regulatory Commission and China Banking and Insurance Regulatory Commission. This model of financial supervision system effectively addresses the characteristics of China's current financial market closure [16]. This kind of supervision system can regulate the financial market environment well and maintain financial stability. In order to truly implement Basel III and improve the banking regulatory system, China has promulgated Administrative Measures for the Capital of Commercial Banks based on the reform experience of other countries and in response to its actual situation [17]. This administrative measures were formally implemented in 2013, providing a legal basis for China's financial supervision, which is of great significance and is known as China's version of Basel [18].

Articles 23 of of Administrative Measures for the Capital of Commercial Banks (for Trial Implementation), specify capital adequacy ratios in accordance with Basel III requirements which are banks must have a capital adequacy ratio of at least $8 \%$, a core Tier 1 capital of at least $5 \%$ and a Tier 1 capital of at least $6 \%$ [22]. In addition, China issued the Law of the People's Republic of China on Commercial Banks (revised draft) on October 16, 2020. In order to better respond to and implement Basel III, which establishes basic principles on capital discipline and implements macro-prudential management, a new chapter 4 has been added to the draft. This chapter deals with capital and risk provisions. This essay will discuss the deficiencies of China's regulatory system in conjunction with the revised draft.

From a macro point of view, the current regulatory system in China has not only "one bank and two 
committees" to reach a framework, but also authoritative laws and regulations and supporting documents as the basis. However, China's supporting documents are quite different from Basel III. Compared with other countries' sophisticated and advanced banking regulatory systems, China's regulatory system still has some urgent problems to be solved [19].

\subsection{Inadequacy of the regulatory system}

Due to the rapidly changing international and domestic financial markets, financial risks cannot be completely avoided. The problem with China's banking supervision system is that there are some problems that have not been resolved due to traditional factors, as well as legal and regulatory gaps, under the framework of "one bank and two committees" [16]. The inadequacy of the regulatory system is mainly manifested in three aspects, the first is that inadequate implementation of the macro-prudential regulatory system [12], the second is the information disclosure system is not perfect [16] and the third is the lack of foresight in the system [21].

Firstly, the macro-prudential supervision system is not yet complete. In the present draft section 62, which places further emphasis on separate management from the original section, it provides that "commercial banks must not engage in trust investment and securities business within the territory of the People's Republic of China, and must not invest in non-self-use real estate or non-bank financial institutions and enterprises" [20]. Thus, it can be seen that in China's regulation of the banking sector has focused on separate operations and separate management, and there have also been reforms in macro-prudential regulation, but some shortcomings remain. However, the principle implemented in Basel III is that the regulator should supervise the regulated throughout the process and implement macro regulation [12]. Besides, UK and European Union have also started to gradually reform from separate management to a unified regulatory regime. According to the legal provisions and practice of China's, the existing regulation of the banking industry is mainly characterized by the disposal or rectification after the fact, but not from the beginning to the end of the implementation of supervision. Even though it is clear in Regulating the Asset Management Business of Financial Institutions that the People's Bank of China (PBOC) shall implement the macro-prudential management philosophy [16]. It also adds the supervisory functions of the PBOC in the draft revision, and section 46 explicitly lists "compliance with macro-prudential management and risk management requirements" [20]. However, there was still a long way to go before unified supervision could be achieved.

Second, the inadequacy of the information disclosure system is another shortcoming of the regulatory system. Basel III has a total of three pillars, the third of which is market discipline. One of the main ways in which market discipline is imposed is through timely and accurate disclosure of information on commercial banks and increased transparency [10]. On the one hand, in section 42 of the draft provides that "commercial banks shall establish a sound management system for information disclosure and shall fulfill their obligation to disclose information in accordance with the law" [20]. However, there is more than one law regulating disclosure principles, such as Chapter 9 of Administrative Measures for the Capital of Commercial Banks (for Trial Implementation) and Measures for the Information Disclosure of Commercial Banks. The problem is that, faced with the legal question of disclosure of information, there are several laws that regulate it at the same time. The method and intensity of regulation and the standards of application vary from law to law. Thus, the question arises as to which law applies, which will lead to different guidelines being adopted by banks[10]. It follows that this does not facilitate the implementation of information disclosure by banks and does not facilitate management, so there is an urgent need to harmonize the standards of information disclosure. On the other hand, due to traditional Chinese factors, command management is used in all industries. Although the banking industry now has an internal complaint and employee reporting mechanism, it is largely ineffective, and China still has a gap compared to developed countries. If the system can be truly implemented, it will lead to better, more open and transparent disclosure of information, and also prevent excessive power and poor decision making by leaders, which will bring risks and losses to the banking industry [19].

Finally, the regulatory system lacks foresight. The law is inherently lagging behind, and with the rapid development of finance, there are a variety of financial products. This leads to the possibility of emerging financial products in the financial markets that are not regulated by existing laws. The most typical representative of this financial product is $\mathrm{Yu}$ Ebao in Alipay, and there is some academic controversy over the definition and classification of the nature of $\mathrm{Yu}$ Ebao[12]. The academic controversy still exists, so it can be seen that for the new financial products, there is also a gap in the legal regulation and supervision. This is the lack of a certain degree of institutional foresight. Therefore, the supervision and management system should not be limited to the existing financial institutions and products, but should be forward-looking, so that the emergence of new financial products in the future can also have a legal basis. 


\section{RECOMMENDATIONS FOR CHINA'S REGULATORY REGIME UNDER THE BASEL III FRAMEWORK}

Because China has some gaps with other countries in terms of operability and technical issues in banking supervision [19], and unlike private ownership of foreign banks, the People's Bank of China is owned by the state. However, as long as it is willing to formulate and improve a regulatory system with Chinese characteristics based on its own national conditions and characteristics, and draw lessons from other developed countries' banking regulatory system reform experience and practical experience.

\subsection{Strengthening macro-prudential management and establishing integrated regulatory systems}

Basel III implements the principle of combining macro-prudential and micro-prudential approaches to regulation [21]. Moreover, in the aftermath of the financial crisis, this type of reform approach has been favoured by countries such as the US and the EU [12]. Although China has made changes in macro-prudential supervision, there are still some shortcomings. The implementation of a combination of macro and micro regulatory methods will be the general trend, only with micro-prudential supervision as a complementary situation, the macro regulatory objectives can be achieved [21]. So as to improve the regulatory system of China's banking industry, so as to have a unified regulatory system. Therefore, China should gradually change the current regulatory system.

\subsection{Improving the information disclosure system}

Firstly, according to section 162 of the Administrative Measures for the Capital of Commercial Banks (for Trial Implementation), the banking industry shall ensure that the disclosed information is true, accurate and complete, therefore, the regulator shall conduct random checks from time to time in order to ensure that the information meets the above requirements. Second, the terms of the disclosure should be refined. This would better protect the right of consumer to information and improve transparency in the banking sector and the viability of the system.

\subsection{Other recommendations}

The bank's internal regulatory system should be improved in three ways: first, improve the internal governance structure, second, improve the accountability system of the board of directors, and third, strictly control the senior management entry standards.
Firstly, the main solution to improve the internal control regulatory system is to improve the internal structure of the company and clarify the rights and responsibilities of each department within the banking industry. For example, the rights and responsibilities of the board of directors and the supervisory board should be clearly delineated [11]. The board of directors should exercise the right of supervision in the pre-matter and decision-making process stages, while the supervisory board is responsible for exercising the right of supervision in the post-matter stage [11]. This division of powers and functions is necessary for the orderly functioning of the internal control system.

Secondly, attention is paid to the role of the board of directors' accountability system in the internal regulatory control system. The board of directors is fully capable of taking on the task of developing and implementing norms of corporate governance, developing strategic plans and so on [11]. In addition, for globally important banks, it is necessary to establish a specialized internal control system, such as a related transaction control committee, which would greatly enhance the professionalism and specialization of the supervisory system [11].

Finally, the entry requirements for senior managers are strictly controlled [19]. As mentioned above, due to traditional Chinese factors, the administration has always been command-and-control. Therefore, under this management model, it is particularly important to raise the entry standards of senior executives in order to prevent them from making decisions that pose risks to the bank due to the pursuit of their own interests. In addition, when faced with risks, senior managers should be professionally qualified to review, control and even mitigate them [19].

\section{CONCLUSION}

In summary, China became a member of the Basel Committee in 2009, an important point for accelerating the upgrading and reform of China's banking supervision [12]. Basel III, which has undergone many revisions since its promulgation, is a summary of the lessons learned from the financial crisis and a valuable guide to mitigate future risks. No country's banking regulatory system is perfect and flawless. However, to achieve a more perfect regulatory system has to undergo continuous practice and development. Therefore, at a time when the world banking industry is developing rapidly, China should foresee the potential risks and problems behind it [12], learn from the experience and lessons of other countries on banking regulatory reform under the Basel III framework, and combine its own characteristics to establish a set of rigorous and operable regulatory system. 


\section{REFERENCES}

[1] Boora, Krishan, Krishan Kavita. "Implementation of Basel III Norms in Banking Industry: A Review of Empirical Literature." IUP Journal of Bank Management 17, no. 3 (August 1, 2018): pp. 7 24.

DOI: http://search.proquest.com/docview/2104963694/.

[2] Aathira, K, R Shanthi. "Basel III - The Impact on Banking Sector." Sumedha Journal of Management 2, no. 2 (April 1, 2013): pp. 4-10. DOI:

http://search.proquest.com/docview/1415741044/.

[3] Fidrmuc, Jarko, Ronja Lind. "Macroeconomic Impact of Basel III: Evidence from a Meta-Analysis.” Journal of banking \& finance 112 (March 2020): pp. 1-14.

[4] Hossain, Md Zakir, Md Atiqur Rahman Khan, M. Shibley Sadique. "Basel III and Perceived Resilience of Banks in the BRICS Economies." Applied Economics 50, no. 19 (April 21, 2018): pp. 2133 - 2146. DOI: http://www.tandfonline.com/doi/abs/10.1080/0003 6846.2017.1391999.

[5] Keefe, Blair, Andrew Pfleiderer. "Basel III: What It Means for the Global Banking System." Banking \& Finance Law Review 27, no. 3 (March 1, 2012): pp. 407-426.

[6] Wikipedia. (2020). Basel III. [online] Available at: https://en.wikipedia.org/wiki/Basel_III\#Capital_req uirements.

[7] Bis.org. (2017). Basel III: Finalising post-crisis reforms. [online] Available at: https://www.bis.org/bcbs/publ/d424.htm.

[8] Lu, Z. and He, F. (2017). Balancing the Capital Charge - A Study of the Revised Basel III Update. [online] app.cibresearch.com. Available at: https://app.cibresearch.com/shareUrl?name $=00000$ 0005ffc4fbe01607c4173ec4b1c [Accessed 15 Oct. 2020].

[9] Basel Committee on Banking Supervision Basel III Monitoring Report. (2020). [online] Available at: https://www.bis.org/bcbs/publ/d500.pdf.

[10] Wu, C., 2014. Research On Banking Supervision Issues Under The Three Frameworks Of Basel Accord. postgraduate. Nanchang University. pp.12-23

[11] LI, J., 2012. Research On My Country's Banking Supervision Legal Issues From The Three Perspectives Of The Basel Agreement. postgraduate. Southwest University of Political Science \& Law.pp.17-29

[12] ZHONG, M., 2014. Banking Supervision System Reform From The Three Perspectives Of Basel Accord In China. postgraduate. Hunan Normal University. pp.33-46 [13] "How US Basel III Rules Could Impact Non-US Banks.” International Financial Law Review (September 1, 2013): n/a. DOI:

http://search.proquest.com/docview/1443818680/.

[13] Wikipedia. (2020b). European Systemic Risk Board. [online] Available at: https://en.wikipedia.org/wiki/European_Systemic_ Risk_Board [Accessed 30 Oct. 2020].

[14] Europa.eu. (2019b). Joint Committee Financial Conglomerates - Objectives and Tasks. [online] Available at:

https://esas-joint-committee.europa.eu/Pages/Activi ties/Financial-Conglomerates-Objectives-and-Task s.aspx.

[15] MA, K., 2018. Implications Of Basel III For The Reform Of China's Financial Regulatory System. postgraduate. University of International Business and Economics. pp.25-61

[16] ZHANG, B., 2016. Analysis Of The Impact Of Basel Implementation On China's Banking Sector. postgraduate. China Foreign Affairs University. pp.10-34

[17] Lee, Ashley. "Asia Bank Capital Series: China's Basel III Regime Explained." International Financial Law Review (December 1, 2013): n/a. DOI: http://search.proquest.com/docview/1498536361/.

[18] WEI, Z., 2015. Research On The Legal System Of Supervision Of Foreign Banks In China - Basel III As A Perspective. postgraduate. Nanchang University. pp.10-20

[19] Law of the People's Republic of China on Commercial Banks (revised draft) (2020)

[20] LUO, Q., 2012. Basel III Challenges And Countermeasures For Capital Regulation Of Commercial Banks In China. postgraduate. Hunan University. pp.13-40

[21] Administrative Measures for the Capital of Commercial Banks (for Trial Implementation) 